\title{
PERCEPTIONS AND PREFERENCES OF ENGLISH STUDENT TEACHERS ON THE ASSESSMENT PRACTICES
}

\author{
Pule Phindane \\ Language and Social Sciences Education, Faculty of Humanities, \\ Central University of Technology, Free State, Bloemfontein 9300 (South Africa)
}

\begin{abstract}
Comprehending the role of assessment and the differential effects on developing students' learning processes is still one of the most explored areas in higher education. The aim of this quantitative study is to investigate English student teachers 'perceptions and preferences on the assessment practices (i.e., formative). The participant were student teachers sampled from the Department of Social Sciences and Language Education, Central University of Technology, Free State, South Africa. The outcomes showed that the assessment practices used by lecturers had an indispensable impact on students' motivation, preparation for future learning tasks, and evaluation of study progress. The data obtained also revealed that while peer assessment is one of the least preferred assessment methods, presentations, self-assessments and research papers were the top preferences. The study outcome relates to previous research while also providing a better understanding into the link between individual differences in the assessment preferences and the learning strategies used by students throughout the years of specialization which might offer lecturers way forward for improving their educational practices.
\end{abstract}

Keywords: Student teachers, perceptions, preferences, assessment practices.

\section{Introduction}

Assessment has been regarded as an integral part in the context of teaching and learning in the higher education. More research (e.g., Carless, 2007; Craddock and Mathias, 2009) has shown that learning is incomplete without assessment because assessment enables the educators to collect pieces of evidence about their students' achievement, scaling and explain their results to decide whether the learning outcomes have been achieved or that some changes and modifications are required. According to Chau and Vien (2020), teachers' instruction is a decisive factor behind students' performance that enables educators to make great attempts to enhance teaching assurance. Al-Dabbus et al (2020) in this regard view assessment as "the process of gathering data" since the instructors will need to prove the achievement of their intended learning outcomes through the data they gather about their teaching and their students' learning.

In normal terms, assessment is categorised as either formative, such as observing students while conducting a learning task, self and peer assessment, question and answer session, application of information, a summary of main points and reflection, or summative particularly when it takes place after the learning is completed and provides information and feedback that sums up the teaching and learning development. This type of assessment is usually conducted in the traditional forms, such as quizzes, midterm and final examinations. However, projects and portfolios could also be used as summative assessments (Al-Dabbus et al, 2020).

In spite of this diversity in the assessment methods, it has been more emphasized that it is the teacher's responsibility to decide which assessment tool should be used to assess his/her students' performance, particularly in the higher education context where academics nowadays are given more responsibility to design and implement diverse methods of assessment in order to fulfil two main demands, which are to increase students' motivation and to achieve quality assurance as represented in achieving the intended learning outcomes (Lynam and Cachia, 2018). Gibbs and Simpson (2004) observed that students' achievement and success in higher education is highly influenced by the assessment system(s) and types that are practiced by their institutions and instructors. Meyer et al. (2010) validate for this finding in the way how assessment can affect the existence of educational institutions or its reputation as a higher education entity within the local or even the international level. 
Investigating the learners' perceptions of their assessment methods can positively impact the emotionality of these learners as well as the workload of their instructors. Craddock and Mathias (2009) emphasise this finding and explains that constant survey of the students' attitudes towards their assessment will lead to more liberal learning in which students are given an opportunity to decide on the choice of assessment method they prefer to have during their learning. Craddock and Mathias (2009) and Gibbs (2006) consider this the transformational target point which should occur to assessment in the higher education context.

\section{Research aim}

This study aims to identify common types of assessment used to assess English student teacher during their study at Central University of Technology (CUT), explore English student teachers' perceptions of those assessment methods, establish the impact of the current assessments on learning from the students' point of view and to suggest alternatives for improving assessment policy for English teacher candidates at CUT.

\section{Research questions}

This study is informed the three main research questions, which are:

1. How do CUT student teacher of English language perceive assessment methods used by their instructors?

2. To what extent such assessment methods influence their learning?

3. What assessment methods are preferred by CUT English student teachers, and why?

\section{Methodology}

The research design used to answer the set of research questions was a quantitative approach. A questionnaire with closed ended question format developed by the researchers was utilised in collecting the data. It consists of twenty-one (21 statements divided into three (3) categories as follows: practices of assessments, impact of assessments on learning and assessment preferences. A five-point Likert type scale ranges from strongly agree to strongly disagree was used. The content validity of the questionnaire was checked by some experts at the university, based on their comments a few modifications were conducted. The questionnaire was chosen as a collection tool in this study as it suits the purpose of the survey and the type of data required.

The total number of participants took part in the study is 50 students, studying in the English Language Education Department, at the CUT during the academic year 2019/2020. They are of different levels: 30 third year students and 20 fourth year students. They were selected randomly and all of them were willing to participate in the study.

\section{Data analysis}

This is a quantitative study that aims to investigate the students' perceptions, preferences of the assessment methods used by their lecturers at the CUT, and the impact of those methods on their learning. The data were collected and analysed as illustrated in the tables below $(1-6)$, which show some descriptive statistics mainly percentages.

\section{Results}

Table 1 demonstrates the responses of the participants regarding their perception towards the practices of assessments given by their instructors. It shows that $30 \%$ of the participants agree that the assessment methods used by their teachers are relevant to their study, whereas $39 \%$ believe that the assessment methods were to some extant relevant. On the other hand, only $1 \%$ was strongly disagree. Concerning to the second statement, the findings indicate that $41 \%$ agree that the assessment methods examine what they know and $43 \%$ of the participants think that the assessment methods to some extent examine what they do in class.

The data also indicate that $31 \%$ of the respondents agree with the statement "the assessment methods examine what my instructor has taught me", whereas slightly higher $32 \%$ to some extent agree with the statement. Regarding the statement that says, "the assessment methods examine my ability to apply what I know in real-life situation", the results show that $15 \%$ strongly agree, $28 \%$ agree and $29 \%$ to some extent agree whereas $16 \%$ disagree. Furthermore, the findings of the study reveal that $31 \%$ agree that "the 
assessment methods have been spread out over the semester". It also shows that $35 \%$ of the total participants strongly agree that their instructors inform them in advance when they would be assessed and in contrast, $0 \%$ strongly disagree. In addition, $40 \%$ agree that they were told in advance what would be assessed. However, the most striking finding revealed by the study is that $42 \%$ to some extent agree that the assessment methods are associated with clear instructions given by the instructor, whereas $28 \%$ agree. The results indicate that $35 \%$ to some extent agree that the assessment methods are attached with clear marking scheme/policy. Similar ratio believe that the assessment types usually vary between formative and summative. $36 \%$ of the respondents reported that the assessments suit my ability whereas $38 \%$ think the assessments are challenging.

Table 1. Practices of assessments.

\begin{tabular}{|l|l|l|l|l|l|}
\hline $\begin{array}{l}\text { Statement } \\
\text { Practices of assessments }\end{array}$ & $\begin{array}{l}\text { Strongly } \\
\text { Agree }\end{array}$ & Agree & $\begin{array}{l}\text { To some } \\
\text { Extent }\end{array}$ & Disagree & $\begin{array}{l}\text { Strongly } \\
\text { Disagree }\end{array}$ \\
\hline $\begin{array}{l}\text { The assessment methods used by my } \\
\text { instructors are relevant to my study }\end{array}$ & $24 \%$ & $30 \%$ & $39 \%$ & $6 \%$ & $1 \%$ \\
\hline $\begin{array}{l}\text { The assessment methods examine what I } \\
\text { know. }\end{array}$ & $11 \%$ & $41 \%$ & $31 \%$ & $14 \%$ & $3 \%$ \\
\hline $\begin{array}{l}\text { The assessment methods examine what I do in } \\
\text { class }\end{array}$ & $9 \%$ & $30 \%$ & $43 \%$ & $14 \%$ & $5 \%$ \\
\hline $\begin{array}{l}\text { The assessment methods examine what my } \\
\text { instructor has taught me }\end{array}$ & $21 \%$ & $31 \%$ & $32 \%$ & $10 \%$ & $5 \%$ \\
\hline $\begin{array}{l}\text { The assessment methods examine my ability } \\
\text { to apply what I know in real-life situation }\end{array}$ & $15 \%$ & $28 \%$ & $29 \%$ & $16 \%$ & $11 \%$ \\
\hline $\begin{array}{l}\text { The assessment methods have been spread out } \\
\text { over the semester }\end{array}$ & $18 \%$ & $31 \%$ & $28 \%$ & $12 \%$ & $12 \%$ \\
\hline I am told in advance when I would be assessed & $35 \%$ & $34 \%$ & $25 \%$ & $6 \%$ & $0 \%$ \\
\hline $\begin{array}{l}\text { I am told in advance on what I would be } \\
\text { assessed }\end{array}$ & $28 \%$ & $40 \%$ & $26 \%$ & $4 \%$ & $3 \%$ \\
\hline $\begin{array}{l}\text { The assessment methods are associated with } \\
\text { clear instructions given by the instructor. }\end{array}$ & $20 \%$ & $28 \%$ & $42 \%$ & $9 \%$ & $1 \%$ \\
\hline $\begin{array}{l}\text { The assessment methods are attached with } \\
\text { clear marking scheme/policy }\end{array}$ & $26 \%$ & $31 \%$ & $35 \%$ & $4 \%$ & $4 \%$ \\
\hline $\begin{array}{l}\text { The assessment types usually vary between } \\
\text { formative and summative }\end{array}$ & $16 \%$ & $34 \%$ & $35 \%$ & $13 \%$ & $1 \%$ \\
\hline The assessments suit my ability & $11 \%$ & $36 \%$ & $33 \%$ & $15 \%$ & $5 \%$ \\
\hline The assessments are challenging & $25 \%$ & $38 \%$ & $34 \%$ & $1 \%$ & $1 \%$ \\
\hline
\end{tabular}

Table 2. Impact of assessments on learning.

\begin{tabular}{|l|l|l|l|l|l|}
\hline $\begin{array}{l}\text { Statement } \\
\text { Impact of assessments on learning }\end{array}$ & $\begin{array}{l}\text { Strongly } \\
\text { Agree }\end{array}$ & Agree & $\begin{array}{l}\text { To some } \\
\text { Extent }\end{array}$ & Disagree & $\begin{array}{l}\text { Strongly } \\
\text { Disagree }\end{array}$ \\
\hline $\begin{array}{l}\text { The assessments assist me in achieving the } \\
\text { course outcome }\end{array}$ & $24 \%$ & $30 \%$ & $39 \%$ & $6 \%$ & $1 \%$ \\
\hline $\begin{array}{l}\text { The assessment methods motivate me to } \\
\text { continue learning }\end{array}$ & $11 \%$ & $41 \%$ & $31 \%$ & $14 \%$ & $3 \%$ \\
\hline $\begin{array}{l}\text { The assessment methods prepare me for the } \\
\text { next learning activities }\end{array}$ & $9 \%$ & $30 \%$ & $43 \%$ & $14 \%$ & $5 \%$ \\
\hline $\begin{array}{l}\text { The assessment methods enable me to evaluate } \\
\text { my progress/improvement/growth in my study }\end{array}$ & $21 \%$ & $31 \%$ & $32 \%$ & $10 \%$ & $5 \%$ \\
\hline
\end{tabular}

Table 2 presents the data concerning the impact of assessments on learning. It shows that $41 \%$ of the participants to some extent agree with the statement "the assessments assist me in achieving the course outcomes" and $37 \%$ agree whereas only $4 \%$ disagree. As indicated in table 2, $25 \%$ of the total samples disagree with the statement "the assessment methods motivate me to continue learning", and $22 \%$ agree with the same statement and very few of them strongly disagree (9\%). Of the total respondents, $35 \%$ agree that the assessment methods prepare them for the next learning activities, in contrast, only $5 \%$ disagree. Highest numbers of the respondents 34\% reported that the assessment methods enable them to evaluate their progress/improvement/growth in their study, while 33\% to some extent agree and only $4 \%$ strongly disagree. 
Table 3. preferences of assessment tools when they are used for formative assessment. $75 \%$ of year 4 participants responded to this statement.

\begin{tabular}{|l|l|l|l|l|l|l|l|}
\hline $\begin{array}{l}\text { Students' } \\
\text { level }\end{array}$ & $\begin{array}{l}\text { Order of } \\
\text { preferences }\end{array}$ & Presentation & $\begin{array}{l}\text { Final } \\
\text { Project }\end{array}$ & Portfolio & $\begin{array}{l}\text { Research } \\
\text { Paper }\end{array}$ & $\begin{array}{l}\text { Self- } \\
\text { assessment }\end{array}$ & $\begin{array}{l}\text { Peer } \\
\text { assessment }\end{array}$ \\
\hline \multirow{4}{*}{$\mathbf{4}^{\text {th }}$ Year } & $\mathbf{1}^{\text {st }}$ & $15 \%$ & $5 \%$ & $0 \%$ & $20 \%$ & $20 \%$ & $10 \%$ \\
\cline { 2 - 8 } & $\mathbf{2}^{\text {nd }}$ & $10 \%$ & $25 \%$ & $15 \%$ & $5 \%$ & $10 \%$ & $15 \%$ \\
\cline { 2 - 8 } & $\mathbf{3}^{\text {td }}$ & $5 \%$ & $0 \%$ & $25 \%$ & $10 \%$ & $25 \%$ & $10 \%$ \\
\cline { 2 - 8 } & $\mathbf{5}^{\text {th }}$ & $10 \%$ & $5 \%$ & $10 \%$ & $10 \%$ & $10 \%$ & $30 \%$ \\
\cline { 2 - 8 } & $6^{\text {th }}$ & $30 \%$ & $35 \%$ & $20 \%$ & $5 \%$ & $10 \%$ & $0 \%$ \\
\hline
\end{tabular}

Table 3 shows the participants of year 4 preferences of the different assessment methods when they are used for formative assessment. It illustrates that $15 \%$ of them chose presentation as their first preference whereas $30 \%$ consider it as their 6 th preference. Only 5\% prefer final project as their first choice and $35 \%$ consider final project as their 5 th preference. None of them chose portfolio as their first preference, whereas $25 \%$ consider it as $3 \mathrm{rd}$ and $20 \%$ as 5 th preference. Research paper was the first preference of $20 \%$ of the participants and $25 \%$ as 6 th preference. Similarly, $20 \%$ chose self - assessment as their first preference and $25 \%$ as $3 \mathrm{rd}$. the data indicate that $30 \%$ of year 4 participants chose peer assessment as their 4 th choice and only $10 \%$ as 1 st.

Table 4. Preferences of assessment tools when they are used for formative assessment. $40 \%$ of year 3 participants responded to this statement.

\begin{tabular}{|l|l|l|l|l|l|l|l|}
\hline $\begin{array}{l}\text { Students' } \\
\text { level }\end{array}$ & $\begin{array}{l}\text { Order of } \\
\text { preferences }\end{array}$ & Presentation & $\begin{array}{l}\text { Final } \\
\text { Project }\end{array}$ & Portfolio & $\begin{array}{l}\text { Research } \\
\text { Paper }\end{array}$ & $\begin{array}{l}\text { Self- } \\
\text { assessment }\end{array}$ & $\begin{array}{l}\text { Peer } \\
\text { assessment }\end{array}$ \\
\hline \multirow{5}{*}{$3^{\text {rd }}$ Year } & $1^{\text {st }}$ & $7 \%$ & $3 \%$ & $0 \%$ & $13 \%$ & $13 \%$ & $3 \%$ \\
\cline { 2 - 7 } & $2^{\text {nd }}$ & $0 \%$ & $10 \%$ & $10 \%$ & $0 \%$ & $7 \%$ & $13 \%$ \\
\cline { 2 - 8 } & $3^{\text {rd }}$ & $10 \%$ & $7 \%$ & $10 \%$ & $3 \%$ & $3 \%$ & $7 \%$ \\
\cline { 2 - 8 } & $4^{\text {th }}$ & $13 \%$ & $3 \%$ & $7 \%$ & $7 \%$ & $3 \%$ & $7 \%$ \\
\cline { 2 - 8 } & $5^{\text {th }}$ & $3 \%$ & $7 \%$ & $3 \%$ & $13 \%$ & $3 \%$ & $10 \%$ \\
\cline { 2 - 8 } & $6^{\text {th }}$ & $7 \%$ & $10 \%$ & $10 \%$ & $3 \%$ & $10 \%$ & $0 \%$ \\
\hline
\end{tabular}

\section{Discussion}

The main aim of the current study was to determine the student teachers' perceptions of the assessment methods used by their lecturers at the CUT, and to what extent such assessments influence their learning. The results of this study reveal several aspects that reflect the perception of the English language student teachers towards the assessment methods used by their lecturers at CUT. Most importantly, the findings align with Lynam \& Cachia (2018); Lizzio \& Wilson (2013), who highlighted the point that, eventually, students' preferences of the assessment methods "have several differential effects on students' learning processes." Despite agreeing that the practices of assessment used by their lecturers were relevant; examined what was taught and learned and suited their abilities, however, most of the student teachers were still uncertain about neither the assessment practices' ability to examine what they do in class and/nor apply what they know in real-life situations.

The second question of this study questioned the impact of assessment practices on student teachers' learning. While third of the responses ranged between 'agree' and 'strongly agree' stating the impact of the assessment practices on the student teachers' motivation; preparation for future learning tasks, and evaluation of study progress and improvement, almost half of the number of the respondents were uncertain that the assessment methods used helped them in achieving the course outcomes. Birenbaum (1997) found 
that "individual differences in assessment preferences overshadow group differences and that differences in assessment preferences correlate to a relatively large extent with learning strategies." Indeed, some questions for further research present themselves here. For example, what is the impact of a particular method (s) of assessment on student teachers' learning approaches? How does this influence their learning in general? How do their learning styles correlate with their preferences of assessment practices, and to what extent?

To maximize student learning experiences, CUT lecturers might consider highlighting the importance of peer assessment at the planning stage; taking into the consideration the findings of Vickerman's (2009) study. The study investigated undergraduate students' perceptions of formative peer assessment. The findings revealed that, even though peer assessment was a positive experience in enhancing students learning and development, "consideration needs to be taken to address individual learning styles, as a limited number of students found the process to be less useful."

\section{Conclusion}

This study investigated the perceptions of student teachers at Central University of Technology, Free State of the assessment methods used by their lecturers. The findings revealed that student teachers need their lecturers to create direct assessment methods, which are, not only aligned with the learning outcomes, but also provided with clear in-advance instructions. The findings showed that the assessment practices used by instructors had an impact on students' motivation, preparation for future learning tasks, and evaluation of study progress. Finally, the findings of this study suggest that further research could be conducted in investigating the influence of different assessment practices on student teachers' learning approaches, and how this influence if any, might correlate with their preferences and learning styles.

\section{References}

Al-Dabbus (2020). Fawzi, H. Al-Wadi, H. (2020). Pre-service English language Teachers' perceptions and preferences of assessment Practices. International Journal of English language and Linguistics Research, Vol.8 (5): 14 - 26.

Birenbaum, M. (1997). Assessment preferences and their relationship to learning strategies and orientations. Higher Education, 33: 71-84.

Carless, D. (2007). Learning-oriented assessment: Conceptual bases and practical implications. Innovations in Education and Teaching International 44: 57-66.

Chau, T \& Vien, T. (2020). Student Evaluation of teaching effectiveness: EFL Teachers' and Students perceptions. International Journal of Education, Learning and Development, Vol 8(6): 1-19.

Craddock, D., and H. Mathias. (2009). Assessment options in Higher Education. Assessment \& Evaluation in Higher Education 34: 127-140.

Gibbs, G. \& Simpson, C. (2004). Does your assessment support your students' learning? Journal of Teaching and Learning in Higher Education, 1(1), 1-30.

Gibbs, G. (2006). How assessment frames student learning. In Innovative Assessment in Higher Education. C.Bryan and K. Clegg (eds), 23-36. Oxford: Routledge.

Lizzio, A. and Wilson, K. (2018). First year students' appraisal of assessment tasks: Implications for efficacy, engagement and performance. Assessment \& Evaluation in Higher Education, 38(4), 389-406.

Lynam, S. \& Cachia, M. (2018) Students' perceptions of the role of assessments at higher education, Assessment \& Evaluation in Higher Education, 43:2, 223-234.

Meyer, L.; Davidson, S.; McKenzie, L.; Rees, M.; Anderson, H.; Fletcher, R.; \& Johnson, P.M. (2010). An investigation of tertiary assessment policy and practice: Assessment and contradictions. Higher Education Quarterly, 64(3), 331-350.

Vickerman, P. (2009) Student perspectives on formative peer assessment: an attempt to deepen learning? Assessment \& Evaluation in Higher Education, 34:2, 221230. 